\title{
PENGARUH PENGGUNAAN MODEL PEMBELAJARAN ROLE PLAY DALAM PENINGKATAN IMPROVISASI BERMAIN PERAN PADA SISWA KELAS VIII SMP TARUNA SURABAYA
}

\author{
Nuril Huda ${ }^{1}$, Imayah ${ }^{2}$ \\ 1,2 Universitas Dr. Soetomo Surabaya \\ nuril.huda@unitomo.ac.id \\ imayah@unitomo.ac.id
}

\begin{abstract}
Abstrak
Berdasarkan hasil refleksi awal dapat dilihat kemampuan improvisasi untuk memainkan peran siswa kelas VIII SMP Taruna Surabaya rendah. Skor kemampuan siswa untuk berimprovisasi bermain peran di 54,62 dan mencapai 31,64 pencapaian KKM\%. Masalah yang diidentifikasi terkait dengan kemampuan siswa untuk berimprovisasi adalah dalam hal pengucapan, intonasi, dan gerak ekspresi. Untuk mengatasi masalah ini peneliti menerapkan model role play. Penelitian ini adalah penelitian tindakan kelas. Subjek penelitian adalah siswa kelas VIII SMP Taruna Surabaya semester ganjil tahun akademik 2018/2019, yang berlokasi di Jl. Mejoyo I No.2, Surabaya. Data penelitian ini meliputi kegiatan siswa dan guru. Teknik pengumpulan data yang digunakan dalam penelitian ini adalah observasi dan tes kinerja yang selanjutnya dianalisis dengan teknik deskriptif dan statistik deskriptif. Berdasarkan hasil penelitian, dapat disimpulkan bahwa model pembelajaran role play dapat meningkatkan kemampuan bermain peran improvisasi siswa kelas VIII SMP Taruna Surabaya. Hal ini dapat dilihat pada tiga aspek yaitu1) pada siklus 1 aktivitas guru meningkat sebesar $60 \%$ menjadi $100 \%$ pada siklus 2) aktivitas pada siklus 1 siswa masih belum berkinerja baik, persentase siklus 1 adalah 74,38\%, sedangkan pada siklus 2 mengalami peningkatan sebesar 94,38\%; 3) Hasil tes kemampuan siswa untuk berimprovisasi bermain peran dengan menggunakan model pembelajaran bermain peran pada siklus 1, 23 siswa dapat mencapai dengan persentase ketuntasan klasikal 65,72\%. Sedangkan pada siklus 2 meningkat menjadi 34 siswa mencapai penguasaan klasikal dengan persentase $97,14 \%$.
\end{abstract}

Kata kunci: Kemampuan improvisasi, Model role play

\section{PENDAHULUAN}

Guru dituntut bersikap responsif terhadap persoalan yang dihadapi dalam pembelajaran di kelas agar kegiatan belajar mengajar yang dilakukan dapat mencapai hasil yang maksimal. Salah satu tuntutan guru dalam menghadapi kegiatan belajar mengajar adalah pembelajaran dalam keterampilan berbahasa. Keterampilan berbahasa mencakup empat keterampilan yaitu keterampilan menyimak, Keterampilan membaca, Keterampilan menulis dan Keterampilan berbicara (Tarigan, 2008:1). Salah satu dari keterampilan berbahasa yang akan dibahas peneliti adalah keterampilan berbicara. 
Menurut Kulup (2009:12), keterampilan berbicara merupakan keterampilan menyampaikan pesan melalui bahasa lisan untuk mengekspresikan, menyatakan, serta menyampaikan pikiran, gagasan dan perasaan. Nurgiyantoro ( 2001: 276 ) menjelaskan bahwa berbicara adalah keterampilan berbahasa kedua setelah menyimak. Seseorang dapat mengucapkan bunyi- bunyi artikulasi setelah mereka menyimak bunyibunyi bahasa tersebut. Senada dengan Douglas (2001: 253) menyatakan bahwa berbicara sebagai salah satu aspek kemampuan berbahasa yang berfungsi untuk menyampaikan informasi secara lisan. Berdasarkan beberapa pengertian yang dikemukakan di atas, dapat disimpulkan bahwa berbicara adalah suatu kemampuan seseorang untuk bercakap-cakap dengan mengujarkan bunyi-bunyi bahasa untuk menyampaikan pesan berupa ide, gagasan, maksud atau perasaan untuk melalakukan interaksi dengan orang lain. Ini berarti bahwa berbicara merupakan sebuah kegiatan/aktivitas kebahasaan yang bertujuan sebagai sarana komunikasi secara lisan.

Berdasarkan hasil pembicaraan peneliti dengan guru mata pelajaran Bahasa Indonesia SMP Taruna Surabaya, diperoleh informasi bahwa di kelas masih banyak permasalahan yang dihadapi dalam pembelajaran Bahasa Indonesia. Salah satunya adalah berkaitan dengan kemampuan siswa ketika mereka bermain peran, Rendra, (1988:7) mengungkapkan bahwa Bermain peran adalah salah satu bentuk pembelajaran, dimana peserta didik ikut terlibat aktif memainkan peran-peran tertentu. Kemudian menurut pendapat lain Dhieni, (2007:70) bermain peran adalah memerankan tokoh atau benda disekitar siswa dengan tujuan untuk mengembangkan daya khayal (imajinasi) dan penghayatan. Jadi kesimpulan dari pengertian bermain peran dari beberapa pendapat diatas adalah mendramatisasikan cara tingkah laku didalam hubungan social dan melibatkan siswa dituntut sertakan dalam mendramatisasikan masalahmasalah hubungan sosial karena melalui kegiatan bermain peran yang menyenangkan, siswa berusaha untuk menyelidiki dan mendapatkan pengalaman yang kaya, baik pengalaman dengan dirinya sendiri, orang lain maupun dengan lingkungan di sekitarnya.

Target Penelitian di salah satu Kompetensi Dasarnya adalah bermain peran dengan cara improvisasi sesuai dengan kerangka naskah yang ditulis siswa, yang dimaksud dengan Improvisasi disini adalah menciptakan plot yang sangat singkat dan mewujudkannya dengan dialog yang tidak direncanakan dan dilatih sebelumnya Saptaria, (2006:94. 
Pendapat lain dari Zaidan, (1991:54) menyatakan bahwa Improvisasi adalah gerakan, ucapan atau lakuan tanpa perencanaan, latihan, atau pelajaran lebih dahulu. Dari beberapa pengertian dapat disimpulkan bahwa improvisasi merupakan suatu aktivitas berperan yang dihasilkan secara spontan dengan menggunakan daya imajinasi, kreativitas dan inovasi seorang aktor berdasarkan rangsangan yang diberikan oleh pasangan atau lawan bermain.

KD tentang bermain peran dengan cara improvisasi sesuai dengan kerangka naskah yang ditulis siswa tersebut belum seluruhnya mencapai KKM (Kriteria Ketuntasan Minimal) yaitu 75. Teridentifikasi beberapa masalah yang berkaitan dengan kemampuan siswa dalam mengimprovisasi bermain peran, masalah-masalah tersebut adalah sebagai berikut. (1) Siswa belum mampu mengimprovisasi dalam bermain peran, (2) Siswa merasa kesulitan mengimprovisasi dalam bermain peran. Munculnya permasalahan tersebut disebabkan oleh (a) Sikap dan minat siswa dalam mengikuti pembelajaran berbicara rendah. Pada umumnya siswa merasa takut dan malu saat ditugasi untuk tampil berbicara di depan temantemannya. (b) Siswa kurang terampil sebagai akibat dari kurangnya latihan berbicara.
Jadi berdasarkan hasil diskusi peneliti dengan Abdul Halim S.Pd. disepakati untuk mengatasi masalah mengimprovisasi dalam bermain peran dengan dilakukan penelitian tindakan kelas. Strategi pemecahan masalah yang dipilih adalah model pembelajaran Role play. Role play berarti suatu cara penguasaan bahan-bahan pelajaran melalui pengembangan imajinasi dan penghayatan siswa (Suryanti, 2008:49). Masalah penelitian ini dapat dirumuskan sebagai berikut. "Apakah penerapan model Role play berpengaruh dalam peningkatan kemampuan improvisasi bermain siswa kelas VIII SMP Taruna Surabaya?". Tujuan dalam penelitian ini adalah untuk meningkatkan kemampuan improvisasi bermain peran Siswa kelas VIII SMP Taruna Surabaya dengan penerapan model pembelajaran Role play. Sebagai indikator keberhasilan pemecahan masalah adalah: 1) Mempermudah siswa dalam terampil berbicara, 2) Mempermudah siswa mengimprovisasi dalam bermain peran.

\section{MODEL PENELITIAN}

Penelitian ini dilaksanakan di SMP Taruna Suarabaya. Subjek dalam penelitian ini adalah siswa kelas VIII dengan jumlah siswa sebanyak 35 siswa yang terdiri atas 14 laki-laki dan 21 perempuan. Penelitian ini dilaksanakan mulai bulan 13 
November s.d. 4 Desember 2018. Sesuai dengan jadwal penelitian, pengambilan data dilakukan pada bulan November s.d. Desember. Kegiatan refleksi awal dilaksanakan pada bulan November 2018. Siklus I dilaksanakan pertengahan bulan November 2018, tepatnya tanggal 13 dan 19 November. Sedangkan siklus 2 dilaksanakan tanggal 26 dan 27 November 2018. Penelitian ini direncanakan menggunakan Penelitian Tindakan Kelas model Spiral dari Kemmis dan Taggart (Wiriaatmadja, 2005:66) dengan dua siklus. Kegiatan masingmasing mencakup (1) rencana tindakan, (2) pelaksanaan tindakan, (3) observasi-evaluasi, (4) refleksi.

\section{Rencana Tindakan Siklus I}

Adapun langkah-langkah perbaikan pembelajaran dirancang sebagai berikut.

a. Guru memberikan salam

b. Siswa dan guru bertanya jawab tentang Bermain drama

c. Guru menjelaskan tujuan pembelajaran yang akan dicapai

d. Memotivasi siswa agar siswa semangat menerima pelajaran

e. Guru membentuk kelompok siswa dalam bermain peran

f. Guru menyuruh siswa untuk membuat skenario yang akan ditampilkan.

g. Guru menyuruh siswa untuk mempelajari skenario dalam waktu singkat sebelum pelaksanaan kegiatan belajar mengajar dimulai.

h. Guru yang menentukan peran pada siswa ketika siswa sudah mulai tampil didepan kelas.

i. Masing-masing kelompok maju ke depan kelas sambil memperagakan skenario sesuai teknik improvisasi masingmasing.

j. Guru menyimpulkan penampilan siswa.

\section{Pelaksanaan Tindakan}

Dalam tahap pelaksanaan tindakan, disepakati oleh peneliti rencana tindakan yang telah disusun. Selanjutnya pelaksana melaksanakan tindakan dalam praktik pembelajaran nyata di dalam kelas. Pelaksana diharapkan benar-benar melaksanakan praktik pembelajaran seperti skenario yang sudah disusun.

\section{Observasi - Evaluasi}

Kegiatan observasi-evaluasi dilakukan oleh peneliti dan guru bersamaan dengan pelaksanaan tindakan yang telah direncanakan. Observasi dilakukan terhadap aktivitas siswa dan guru yang berkaitan dengan aktivitas siswa dalam mengimprovisasi bermain peran, menerapkan model role play. Observasi tersebut dilakukan dengan menggunakan lembar observasi dan lembar penilaian untuk pedoman penilaian. 


\section{Refleksi}

Pada tahap refleksi, data yang diperoleh dari hasil pengamatan tentang aktivitas guru dan kemampuan siswa mengimprovisasi bermain peran selama pelaksanaan tindakan diolah dan dianalisis. Pada tahap refleksi, jika pelaksanaan pada siklus I sudah tuntas tidak akan dibutuhkan lagi siklus berikutnya. Sebaliknya jika pada siklus I masih belum tuntas maka akan dilanjutkan pada siklus berikutnya.

Data penelitian ini meliputi hasil prestasi belajar siswa serta observasi guru dan siswa. Teknik pengumpulan data yang digunakan adalah tes performansi untuk mengetahui keterampilan mengimprovisasi bermain peran dan observasi untuk mengetahui penerapan tindakan yang dilakukan oleh guru, partisipasi, dan keaktifan siswa selama pembelajaran berlangsung.

Analisis data dilakukan dengan menggunakan teknik deskriptif kuantitatif. Untuk mendeskripsikan peningkatan kemampuan mengimprovisasi bermain peran dari siklus I dan siklus selanjutnya dilakukan dengan menghitung dengan rumus sebagai berikut.

1. Analisis Data Hasil Observasi

a. Aktivitas Guru

Dari aktivitas guru yang muncul dapat dihitung dengan rumus sebagai berikut:
$\mathrm{AG}=$ Aktivitas yang muncul $\times$ $100 \%$

Aktivitas keseluruhan

b. Aktivitas Siswa

Aktivitas siswa yang muncul dirumuskan sebagai berikut:

AS $=$ Aktivitas yang muncul $\times 100 \%$

Aktivitas keseluruhan

2. Analisis Data Hasil Tes

a. Untuk nilai KKM individual yaitu siswa harus mendapatkan nilai 75 ke atas.

Skor Individual =Nilai yang diperoleh $100 \%$

Nilai seharusnya

a. Untuk KKM klasikal yaitu $85 \%$ siswa yang tuntas

Ketuntasan Klasikal =

fumlah sis tuntas

$100 \%$

Jumlah siswa keseluruhan

\section{HASIL PENELITIAN}

Pada bab ini memaparkan hasil penelitian yang telah dirumuskan pada RPP (rencana pelaksanaan pembelajaran), lembar pengamatan kinerja guru dan siswa, hasil belajar siswa.

\section{Siklus I}

Pada siklus 1 diketahui bahwa selama pelaksanaan tindakan siklus I dapat dikemukakan bahwa guru sudah melaksanakan tindakan seperti yang telah direncanakan dalam RPP. Guru sudah menjelaskan materi yang terkait tentang menulis kreatif naskah drama 
satu babak. Selain itu pada tindakan siklus I siswa juga sangat antusias dalam mengikuti pelajaran ketika membuat naskah drama.

Pada tindakan siklus I diketahui siswa yang belum mencapai KKM sebanyak 12 siswa. Sedangkan yang sudah mencapai KKM sebanyak 23 siswa.

\section{Siklus II}

Pada siklus II dapat dikemukakan bahwa guru sudah melaksanakan tindakan seperti yang direncanakan dalam RPP. Guru juga sudah menjelaskan tujuan pembelajaran yang akan dicapai dan siswa juga antusias dalam mengikuti pelajaran ketika menyusun kerangka untuk dijadikan sebuah naskah drama.

Pada siklus II diketahui siswa yang belum mencapai KKM sebanyak 1 siswa. Sedangkan yang sudah mencapai KKM sebanyak 34 siswa. Sehingga dari siklus I ke siklus II mengalami peningkatan sebesar.

\section{PEMBAHASAN}

Hasil penelitian Pengaruh model pembelajaran role play dalam meningkatkan kemampuan improvisasi bermain peran siswa kelas VIII dapat diperoleh sebagai berikut.

\section{Observasi Aktivitas Guru}

Hasil observasi aktivitas guru pada siklus I yaitu 3 aktivitas sudah dilaksanakan dengan persentase $60 \%$. Terdapat beberapa aktivitas guru yang belum dilaksanakan pada siklus I yaitu a) guru tidak menyampaikan tujuan pembelajaran pada siswa; b) guru tidak memberikan evaluasi. Hasil observasi pada siklus II mengalami peningkatan. Terdapat 5 aktivitas yang sudah dilaksanakan dengan persentase 100\%. Berikut ini grafik hasil observasi aktivitas guru dalam pembelajaran menulis laporan perjalanan siklus I dan siklus II.

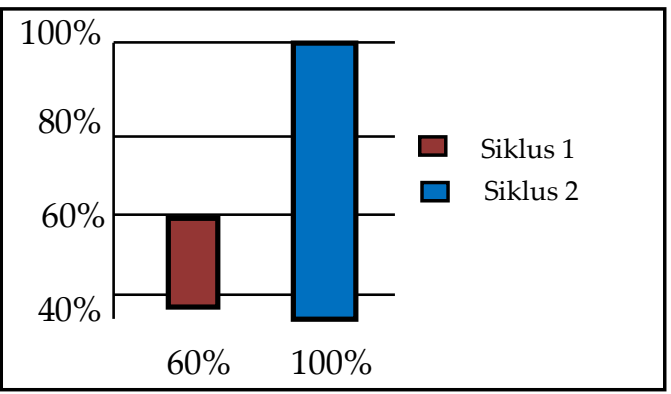

Grafik 4.1 Hasil Observasi Aktivitas Guru

2. Observasi Aktivitas Siswa

Hasil obseravsi aktivitas siswa pada siklus I yaitu $74,38 \%$. Terdapat beberapa aktivitas yang belum dilakukan oleh siswa secara maksimal yaitu a) siswa tidak merespon hasil pekerjaan siswa lain dengan persentase $81 \%$; b) siswa tidak melakukan tanya jawab tentang materi yang disampaikan guru dengan persentase $68 \%$; c) siswa tidak merefleksi materi perjalanan dengan persentase $65 \%$.Hasil observasi aktivitas siswa pada siklus II sudah mengalami peningkatan. Hal ini dapat dilihat pada a) aktivitas siswa bertanya jawab tentang materi yang disampaikan oleh guru; b) siswa merefleksi materi 
pelajaran; dan c) siswa merespon hasil pekerjaan siswa lain. Pada siklus II aktivitas siswa meningkat dengan persentase 94,38\%. Berikut ini grafik hasil observasi aktivitas guru dalam pembelajaran mengimprovisasi bermain peran siklus I \& siklus II.

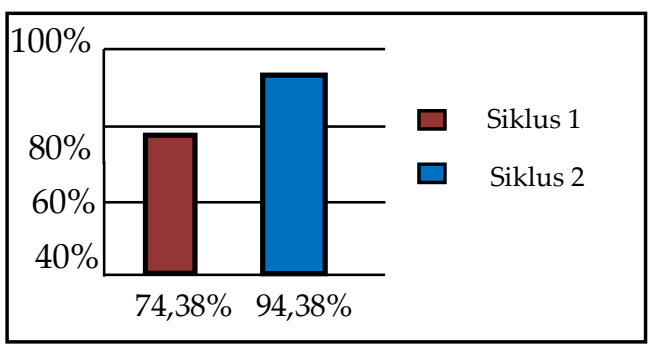

Grafik 4.2 Hasil Observasi Aktivitas Siswa

\section{Hasil Tes Kemampuan Siswa}

Setelah diberi tindakan berupa penerapan model role play pada siklus I menunjukkan adanya peningkatan kemampuan mengimprovisasi bermain peran. Dari hasil siklus I dapat diketahui: a) Presentase kemampuan siswa dalam mengimprovisasi bermain peran dari segi lafal sebesar 17,57\% dengan kriteria baik, b) Presentase kemampuan siswa dalam kemampuan mengimprovisasi bermain peran dari segi intonasi sebesar 19,65\% dengan kriteria baik, c) Presentase kemampuan siswa dalam kemampuan mengimprovisasi bermain peran dari segi gerak sebesar 19,11\% dengan kriteria baik, d) Presentase kemampuan siswa dalam mengimprovisasi bermain peran dari segi ekspresi sebesar 17,14\% dengan kriteria cukup, e) Presentase skor komulatif seluruh aspek/indikator mencapai 73,48\% dengan kriteria baik.

Hasil siklus II juga menunjukkan adanya peningkatan baik per aspek indikatornya maupun secara kumulatif. Dilihat dari hasil per aspek indikatornya dapat diketahui: a) presentase kemampuan siswa dalam mengimprovisasi bermain peran dari segi lafal sebesar 17,4\% dengan kriteria baik, b) presentase kemampuan siswa mengimprovisasi bermain peran dari segi intonasi sebesar 20,57\% dengan kriteria baik, c) presentase mengimprovisasi bermain peran dari segi gerak sebesar 20,62\% dengan kriteria baik, d) presentase mengimprovisasi bermain peran dari segi ekspresi sebesar 17,6\% dengan kriteria baik, e) presentase skor kumulatif seluruh aspek atau indikator mencapai 79,48\% dengan kriteria baik.

Jadi hasil tes kemampuan siswa pada siklus I yaitu $65,72 \%$ ke siklus II mengalami peningkatan. Kesulitankesulitan siswa pada siklus I dapat diatasi pada siklus 2. Hal ini dibuktikan dengan presentase ketuntasan siklus I yaitu 97,14 \%dan ketuntasan siswa meningkat menjadi 97,14 \% pada siklus II. Berdasarkan data tersebut, menunjukkan bahwa mengimprovisasi bermain peran siswa kelas VIII SMP Taruna Surabaya dengan menggunakan model pembelajaran role play dapat meningkat. Berdasarkan penjelasan 
tersebut, dapat dibuat grafik seperti berikut.

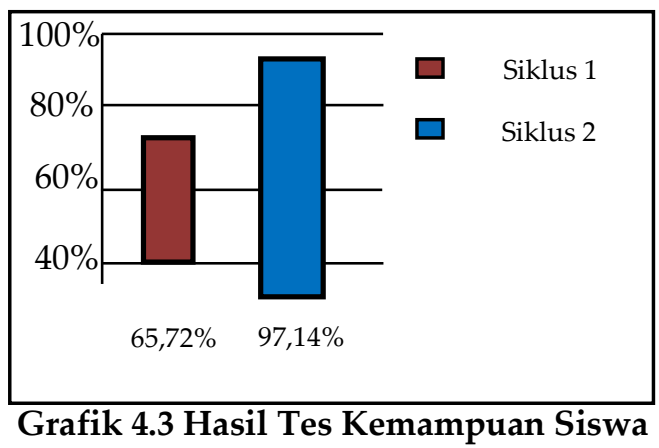

\section{SARAN}

Berdasarkan hasil penelitian, dapat dikemukakan saran sebagai berikut.

1. Kepada guru mata pelajaran bahasa Indonesia, model pembelajaran role play terbukti dapat meningkatkan kemampuan siswa terutama pada kompetensi dasar mengimprovisasi bermain peran. Dengan adanya penelitian ini, guru diharapkan menggunakan model pembelajaran role play pada kompetensi dasar yang lain.

2. Kepada guru mata pelajaran lain, hendaknya dijadikan ide untuk menggunakan model pembelajaran yang sesuai dengan materi yang akan diajarkan.

3. Kepada sekolah, hendaknya memberi fasilitas kepada guru mata pelajaran yang melakukan pembelajaran di kelas dengan menggunakan model pembelajaran inovatif.

\section{DAFTAR PUSTAKA}

Brown, H. Douglas. 2001. Teaching by Principles: An Interactive Approach to Language Pedagogy. Englewood Cliffs, New Jersey: Prentice Hall Regents.

Dhieni, Nurbiana, dkk. 2007. Metode Pengembangan Bahasa. Jakarta: Universitas Terbuka.

Hamzah,B.Uno. Nurdin.Mohamad. 2012. Belajar dengan Pendekatan PAIKEM. Jakarta: Bumi Aksara.

Kulup,Lulukhsani. 2009. Berbicara: Teori dan Penerapan. Surabaya: Abadi Jaya.

Mulyasa. 2010. Kurikulum Tingkat Satuan Pendidikan sebuah panduan praktis. Bandung: PT Remaja Rosdakarya.

Nurgiyantoro, Burhan. 2001. Penilaian dalam Pengajaran Bahasa dan Sastra (Edisi ke- 3). Yogyakarta: BPFE- Yogyakarta.

Rendra.1988. Tentang Bermain Drama. Jakarta: Pustaka jaya

Saptaria, Rikrik. 2006. Panduan Praktis Akting untuk Film dan

Teater.Bandung: Rekayasa Sains Suryanti ,dkk. 2008. Model-Model Pembelajaran Inovatif. Surabaya: Unesa Press

Tarigan,Henry Guntur.1981. Berbicara: Sebagai Suatu Keterampilan Berbahasa. Bandung: Angkasa.

http://jurnalbidandiah.blogspot.com/20

12/04/model-pembelajaran-roleplaying.html\#ixzz2cnkFSrxxdiaks 
es/diunduh, 23 Juli 2018 Pukul

12.01.

library.um.ac.id/ptk/index.php?mod=d

etail\&id=48882.

diakses/diunduh,23 juli 2018

pukul 12.05. 